\title{
Financing Bologna, the Internationally Mobile Students in European Higher Education
}

\author{
MARCEL GÉRARD \\ CESIFO WORKING PAPER NO. 2391 \\ CATEgory 1: Public FinANCE \\ SEPTEMBER 2008
}
An electronic version of the paper may be downloaded
- from the SSRN website: www.SSRN.com
- from the RePEc website: - from the CESifo website:




\title{
Financing Bologna, the Internationally Mobile Students in European Higher Education
}

\begin{abstract}
Despite the importance of the Bologna process for the mobility of students, and the further mobility of graduates, as well as for peace, growth and welfare in that area, nothing has been decided so far for the financing of internationally mobile students, so that the burden of that financing, usually public, is supported by the host country. Moreover in- and outflows of students show imbalances and such imbalances are expected to increase with mobility. Therefore, we first suggest and discuss an alternative system transferring the responsibility for financing higher education to the country of origin of the students (except for those from developing countries). Origin country finances students from its territory through a two-part portable voucher: one part is dedicated to the financing of the true cost of studies, the other part intends to support student's life and might be designed in such a way that some social goals are reached. Those vouchers can be used anywhere in a defined international area provided it is in the designed field of studies and in a school whose quality has been recognized by the issuing country. Some actual systems at work in the world, which prefigure aspects of the proposal, are presented in appendix. Second, we show that, when coupled with a compensation of the origin country in case of international career of the graduate, the system proposed in this paper might be equivalent to a centralized efficient design.
\end{abstract}

JEL Code: H41, H77, I20.

Keywords: Bologna process, higher education, mobility, federalism, subsidiarity, European Union.

\author{
Marcel Gérard \\ Louvain School of Management \\ Catholic University of Mons \\ 151 Chaussée de Binche \\ Belgium - 7000 Mons \\ marcel.gerard@fucam.ac.be
}

This paper is part of research program PAI 6/09 financed by the Belgian Federal Authorities, especially the Ministry of Scientific Policy. I am indebted to the many persons who stimulated this research or have been closely associated to it, especially Vincent Vandenberghe. This paper has been completed when I was visiting UC Berkeley Burch Center and Cattolica University in Milan, stays made possible by a grant from the F.R.S.FNRS, and WZB in Berlin. I am much indebted to Cédric Chevalier for valuable research assistance, as well as to Kai Konrad, Lydia Mechtenberg and Xavier Wauthy for useful comments and Alan Auerbach and Massimo Bordignon for their hospitality. 


\section{Introduction}

Two features have motivated this research. Both are related to the mobility of students across European borders. The first one is the Bologna process; the second one is the imbalance between the in- and out-flows of foreign students observed for some countries, especially Austria and Belgium. That imbalance may prefigure the situation in a more integrated higher education area, especially when the approximation of cultures and the interest for acquiring international and intercultural skills will be further developed.

Although the first feature, the Bologna process, paves the way for a new and large international market for graduates - especially when combined with the free mobility of graduates, one of the four freedoms characterizing the European Union - which can be a serious contribution to peace, welfare and growth in the geographical area concerned, nothing has been provided regarding the financing of students' mobility. Therefore, countries with the best schools will be more attractive for foreign students, but due to the mostly used financing mechanism of higher education, that quality will cost to the residents of the host country. In economic terms, countries with best higher education will provide the other countries with a positive externality. Conversely, countries might be tempted to free ride their better quality neighbors with the risk that such a process eventually downsizes the global quality of higher education in our part of the world.

The second feature is basically an empirical observation, not unrelated with the first one. Many students from France and possibly from The Netherlands are educated in Belgian higher education institutions at the expense of the Belgian taxpayer. In that sense France free rides Belgium, exporting students whose education is uncompleted and getting back enriched human capital four or five years later; roughly speaking those French students are mostly those who failed at the admittance competition for paramedical or veterinary medicine studies in France. That movement is stimulated by the good quality of higher education in Belgium, as well as by the proximity of language, the unrestricted access - at least initially - and the low level of tuition fees in Belgium. The same process appears between Germany and Austria, especially in medicine, and again the larger country free rides its smaller neighbor. That situation creates imbalances amounting to 4.7 per cent of the total number of higher education students in Belgium, and 4.4 per cent, similarly, in Austria - see below.

That situation also involves the appearance of protectionist behaviors from the local governments, like the introduction of quotas - price discrimination based on citizenship being prohibited with respect to students from the European Union. Imposing quotas is exactly the reverse of what the Bologna process aims to stimulate.

Therefore, in order to avoid those negative issues - the development of externalities and free riding and the possible decrease in quality, and the imbalance possibly involving protectionist behaviors -, we suggest transferring the responsibility for financing higher education from the host country, that where the foreign human capital is improved and enriched, to the country of origin of the 
students. The country of origin of the students can be viewed as the one where the students have their permanent residence, or their main attachment, or where they have obtained their high school degree - see Figure 5 below.

Notice immediately that the students whose country of origin is a developing country are not concerned by the institutional device proposed and discussed below. The financing of those students needs to obey other rules. Moreover, mobile students considered in this paper are those who enroll for a term or a degree in an institution abroad; exchange students, like Erasmus students, are not concerned.

The mechanism suggested in this paper consists for the origin country to provide his and her students with a two-part portable voucher that they can use for financing their studies, on the one hand, and for covering the cost of living during the academic year, on the other hand.

The first part of the voucher intends to cover the true cost of studies and might be regarded as a tuition fee voucher. It may be used in any higher education institution of a defined international area - say the Bologna area provided it is used in the field of studies for which it is dedicated and in a school whose quality has been recognized by the country of origin, possibly through a network of certification.

The second part of the voucher is dedicated to finance the cost of living at home or abroad, and can be called a student support voucher. That part might be modulated to take into account dissimilarities in costs of living, or to favor targeted groups of students or fields of studies, or still to compensate extra costs related to the family situation of the student. In short one can say that the second part of the voucher might be equity or fairness-oriented - see Chevalier and Gérard (2008) for details.

The combination of the two parts of the voucher makes it an interesting tool to monitor the choice of the studies, and thus of the careers, as well as to favor a more democratic access to higher education.

Nevertheless, in the analytical developments below we will focus on the first part of the voucher; extension to the second part being straightforward.

Those vouchers can either be provided for free, thus granted, by the responsible government, or they can take the form of a loan, or of a mix of a grant and a loan. This is up to the origin government to take decision in that matter.

However, as we show in the analytical sections of the paper, as long as students going abroad for studies most often come back home after the completion of those studies and then spend their career time in their country of origin, providing vouchers for free might be justified. In a possible future, when the market for graduates will be EU-wide or Bologna-wide actually, grants might become an inefficient design: the origin country then generates positive externalities for the other countries of the area. Therefore the origin country should be compensated for the higher education provided to its past residents working abroad. That compensation can take the form of turning the voucher from a grant to a, possibly contingent, loan, or of an exit, Bhagwati, tax. If the compensation generates a credit against local tax liabilities, it is equivalent that the compensation is paid by the graduate or by the country where he or she works. 
Moreover, one can show that the combination of vouchers granted by the origin country and a compensation in case of international career, makes the outcome of that system equivalent to that of a centralized efficient design.

The practicability of the system depicted above will depend on the integration of the Bologna or otherwise defined area. In the sequel of the paper we speak about the Bologna area. By that term we mean the area covered by a network of bi- or multi-lateral agreements organizing the system suggested and discussed in that paper. The concerned countries already have a long experience of a network of treaties in tax and social security matters so that the institutional design presented here is not infeasible. Roughly speaking, part of what is proposed and discussed in this paper for higher education, already applies in the EU for medical care abroad; and the compensation of the origin country echoes what already applies for soccer players: the club of origin may receive compensation for the initial training of the player during his or her whole career.

Thereafter in this section we come back on the two features motivating the paper as well as on the relevant literature. Then in section 2 we present the proposition of a two-part voucher and characterize its properties. Section 3 introduces the model we use for the formal analysis of the core of the proposal. Sections 4 to 7 are then dedicated to the examination of four institutional designs using the model of section 3 ; those designs respectively are centralization, the current system applying the Production Principle - higher education is financed by the country where schools are located -, the proposed system of vouchers and application of the Origin Principle - higher education students are financed by vouchers provided by their country of origin - and a mechanism where vouchers are completed by a compensation of the origin country in case of international career through grants turned into loans or through a Bhagwati tax. A summary and conclusions are proposed in section 8. The reader will find in appendix how some actual country practices prefigure the system discussed in the paper.

Let us stress that this paper deliberately remains in the European tradition of a system of higher education basically financed through public funds - Aghion et al. (2008). This option is chosen since it is the most realistic in today Europe. Even the scholars who advocate higher education financed basically through contingent loans recognize that those loans should be provided by the public authorities - see the Australian case in appendix - or that those authorities should provide the financial system with public collaterals due to the inefficiency of that credit market. Therefore, like Justmann and Thisse (1997, 2000), we consider that higher education is provided by the public sector for exogenous reasons; see also Andersson and Konrad (2003), Barr (1998) and Poutvara and Kanniainen (2000).

\subsection{The Bologna Process}

The Bologna process is now well known, at least among Europeans. It was launched in the Italian eponym city on June 19, 1999, when the representatives of the Ministers of Higher Education of 31 European countries or sub-national 
jurisdictions signed a common declaration, which intended to achieve some objectives within the first decade of the new millennium.

The philosophy of the Bologna Process is well summarized in the Bologna Declaration. The declaration states that 'A Europe of Knowledge is now widely recognized as an irreplaceable factor for social and human growth and as an indispensable component to consolidate and enrich the European citizenship, capable of giving its citizens the necessary competencies to face the challenges of the new millennium, together with an awareness of shared values and belonging to a common social and cultural space.'

Then signatories recognize the 'Importance of education and educational cooperation in the development and strengthening of stable, peaceful and democratic societies' and 'Universities' central role in developing European cultural dimensions'. They promote the 'creation of the European area of higher education as a key way to promote citizens' mobility and employability and the Continent's overall development.'

In line with this philosophy six main goals were to be implemented

- Adoption of a system of easily readable and comparable degrees in order to promote European citizens employability and the international competitiveness of the European higher education system.

- $\quad$ Adoption of a system essentially based on two main cycles.

- Establishment of a system of credits as a proper means of promoting the most widespread student mobility.

- $\quad$ Promotion of mobility by overcoming obstacles to the effective exercise of free movement.

- $\quad$ Promotion of European cooperation in quality assurance.

- $\quad$ Promotion of the necessary European dimensions in higher education.

Therefore, any restriction to the mobility of students, like quotas, opposes the Bologna Process. The question is then the following: how to reconcile the promotion of students' free mobility with a fair and efficient distribution of the costs, given the European law and general principles, including the tradition of a higher education system extensively financed through the public authorities.

\subsection{Empirical observation: cross-border imbalances in a world of growing student mobility}

At global level, international student mobility seems to have been increasing for a long time, as depicted in Figure 1. However it is unevenly distributed, the flow of foreign students concentrating on some countries, as illustrated by Figures 2, 3 and 4. This produces the imbalances put forward in Table 1. Moreover the concept of foreign student needs to be refined: is he or she a non-citizen, a non-national, someone who obtained his or her previous - high school, bachelor - degree in another country? That issue is illustrated by Figure 5.

Therefore, the quality of global data is questionable. Fortunately, that quality increases when we focus on data at OECD or EU level, and some projects, like Eurydice and Atlas, have been undertaken in order to improve our knowledge. 


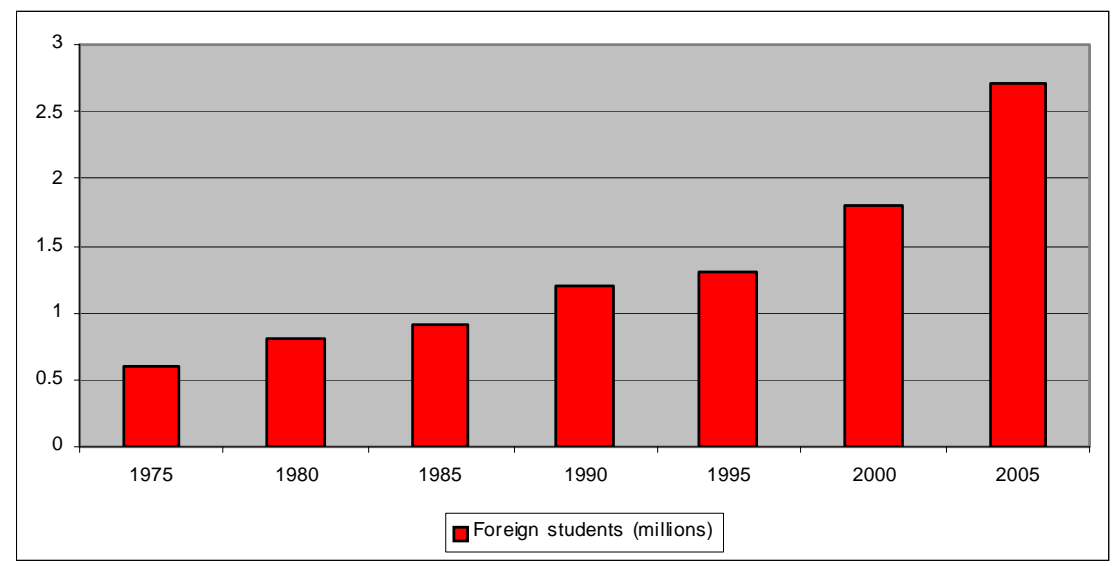

Figure 1 - Evolution of the number of foreign students tertiary education between 1975 and 2005 (OECD (2007), Education at a Glance 2007, indicator C.3, p. 303)

Interestingly, international students' mobility is very concentrated on some countries, as shown in Figures 2 and 3, which also reveal that some countries have lost market shares while some other countries have gained shares between 2000 and 2005.

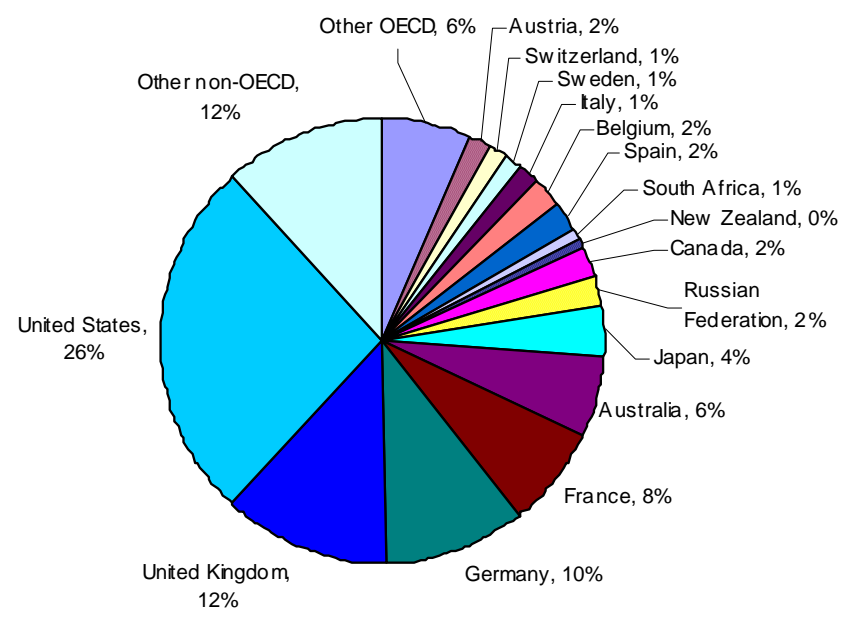

Figure 2 - International higher education market share by country of destination in 2000 (OECD (2007), Education at a glance 2007, indicator C.3, p. 304. 


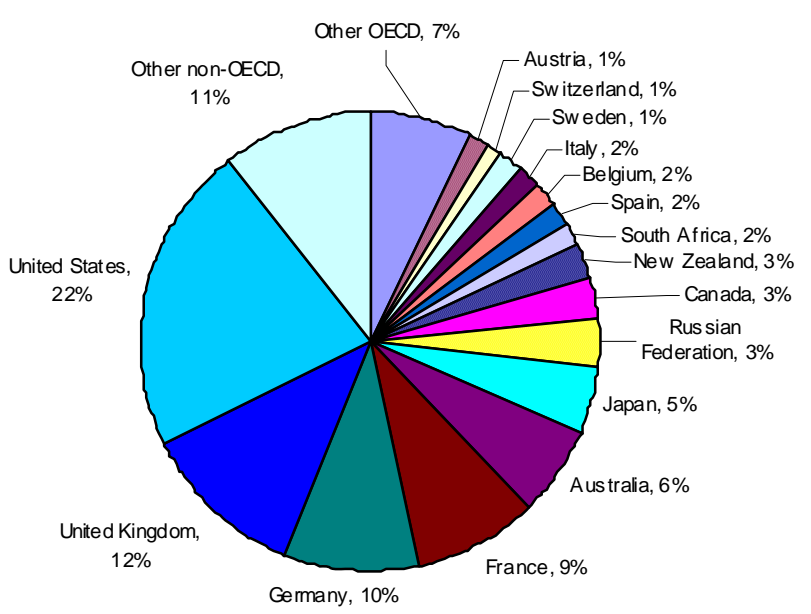

Figure 3 - International higher education market share by country of destination in 2005 (OECD (2007), Education at a glance 2007 , indicator C.3, p. 304

Figure 4 shows the OECD countries with the largest share of foreign students and Table 1 sets forth the imbalance.

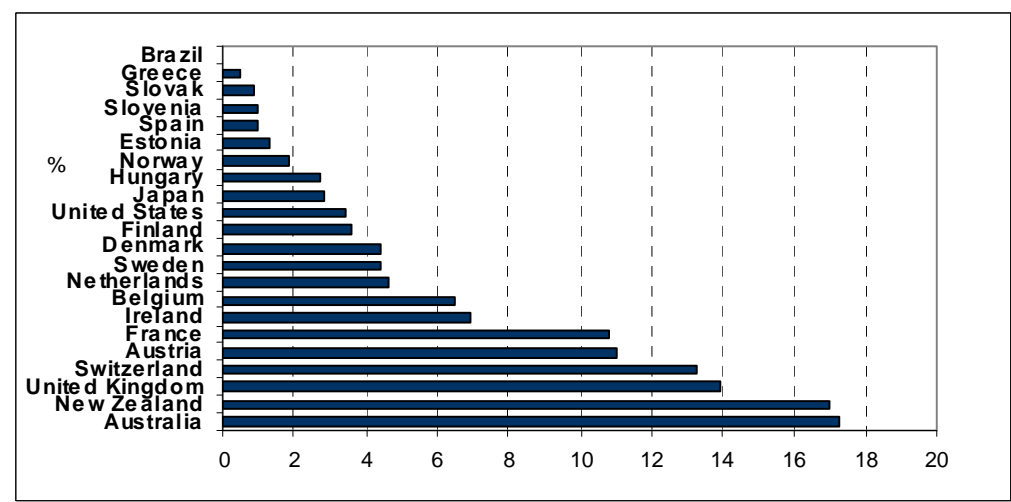

Figure 4 - Share of tertiary education international students per host country in 2005 (OECD (2007), Education at a glance 2007, indicator C.3, p. 298. 


\begin{tabular}{ll|l}
\hline Country & $\begin{array}{l}\text { EU foreign students as } \\
\text { \% of total }\end{array}$ & $\begin{array}{l}\text { Nationals studying } \\
\text { abroad } \begin{array}{r}\text { sinus EU } \\
\text { foreign students as \% } \\
\text { of total }\end{array}\end{array}$ \\
Belgium & $6,46 \%$ & $-4,69 \%$ \\
Austria & $8,07 \%$ & $-4,42 \%$ \\
United Kingdom & $4,04 \%$ & $-3,56 \%$ \\
Sweden & $3,57 \%$ & $-2,65 \%$ \\
Germany & $3,01 \%$ & $-1,82 \%$ \\
Ireland & $2,34 \%$ & $-1,52 \%$ \\
Czech Republic & $2,66 \%$ & $-1,09 \%$ \\
Netherlands & $2,03 \%$ & $-0,75 \%$ \\
Denmark & $1,59 \%$ & $-0,47 \%$ \\
France & $1,63 \%$ & $-0,39 \%$ \\
Spain & $0,51 \%$ & $0,29 \%$ \\
Hungary & $0,91 \%$ & $0,49 \%$ \\
Italy & $0,62 \%$ & $0,65 \%$ \\
Poland & $0,04 \%$ & $1,13 \%$ \\
Portugal & $0,65 \%$ & $1,34 \%$ \\
Finland & $0,63 \%$ & $1,47 \%$ \\
Greece & $0,04 \%$ & $3,15 \%$ \\
Slovak Republic & $0,36 \%$ & $8,35 \%$ \\
Luxembourg & $0,00 \%$ & $187,77 \%$ \\
& &
\end{tabular}

Table 1 - EU originated foreign students in higher education and net (im-) balance as a percentage of the total higher education population (source: Gérard and Vandenberghe, 2007a)

Inspection of Table 1 shows that Belgium and Austria support the cost of other countries higher education. Luxembourg is an example of a country that, to a large extend, externalizes the cost of its citizens' higher education.

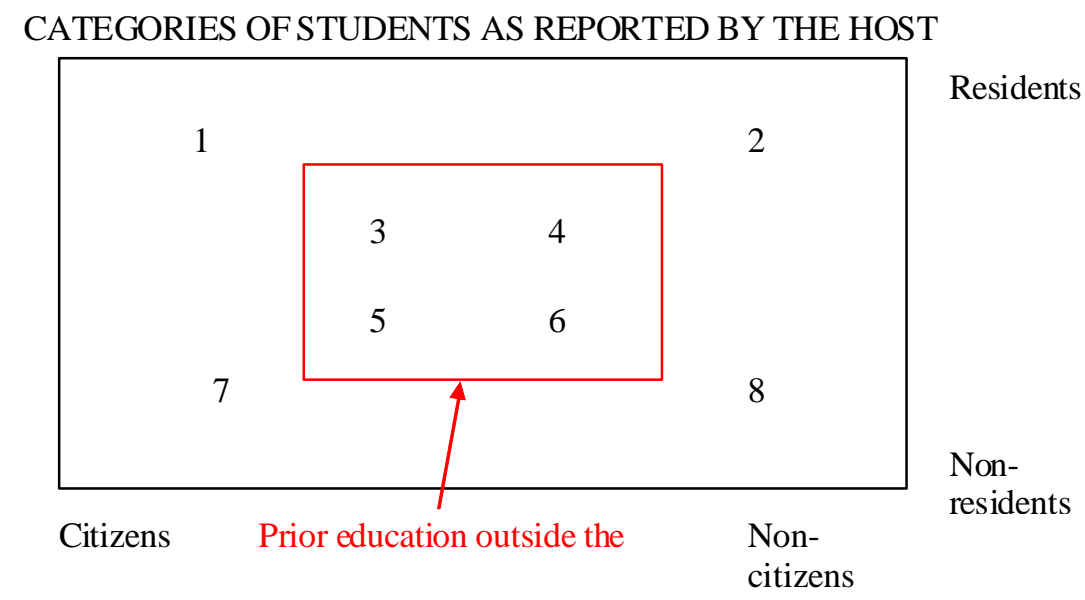

Figure 5 - Various criteria used to define mobile students. 
In the next section we propose a system which can overcome the effects of that imbalance.

\subsection{Related literature}

This paper takes place in a series of contribution by Gérard and coauthors (Gérard 2006a,b, 2007, 2008, Gérard and Vandenberghe, 2007a,b, Chevalier and Gérard, 2008); related literature first includes Mechtenberg and Strausz (2006, 2008), which inspired part of our analysis. As they say, "the relation between mobility and human capital has for long been on the agenda of economic research'.

According to those authors, relevant literature indeed first refers to the contributions on the brain drain (see Grubel and Scott, 1966; Bhagwati and Hamada, 1974). In a similar context, Justman and Thisse (1997, 2000) point out the link between mobility and underprovision of publicly provided education. By contrast, Stark et al. (1997), Beine et al. (2001), and Stark and Wang (2002) also consider private investment in education. More recently, both forms of financing education are taken into account by Poutvara (2004a,b). Quoting Mechtenberg and Strausz again 'the most stable result established by this kind of literature is that although increasing mobility [...] will lead to higher private investment in education, public provision will decrease. The government will tend to free ride on the education system of other country'. Buettner and Schwager (2004) produces similar results while, next to the free-rider effect, Kemnitz (2005) also considers the competition effect for governments providing education to mobile students. The present paper has some features in common with Mechtenberg and Strausz; however, it departs from that contribution by focusing on the issue of which country should be responsible for financing foreign students, regarded from the point of view of efficiency and fiscal federalism.

Interested reader will also read Bache (2006), Sapir et al. (2003), Aghion et al. (2008) and van der Ploeg and Veugelers (2008). Indeed, although the Bologna process concerns a geographic area larger than the territory of the European Union, one can say that, together with the Sapir Report and the Lisbon Agenda, it generates a large debate around higher education in Europe. Finally on vouchers, also called entitlements by some scholars, see also the frequently quoted contribution of Levin (1983); and especially on the application of that mechanism to higher education, see e.g. the discussion proposed by Jongbloed and Koelman (2000).

\section{Proposition: A two-part portable voucher plus international compensation}

In most countries of the Bologna area - an area which encompasses the European Union - higher education is publicly funded and students only pay a small tuition fee. 
Moreover EU legislation prohibits charging foreign EU students a fee different from the one asked from nationals. That latter restriction makes the EU financing of higher education, much different from that prevailing e.g. in the US, where non-residents of the financing state are charged a higher fee, at least for their first year of residence.

It turns out that the cost of EU foreign students is supported by the host country. That cost will go up with the expected increasing mobility of students: countries made attractive by the high quality of their higher education will have to finance an increasing inflow of foreign students and thus to subsidize the enrichment of human capital of other countries. Such a situation, through the externalities generated, can involve inefficiencies, the adoption of restrictive behaviors by governments and an underprovision of publicly funded higher education - see the survey of the literature above. Indeed, countries which experiment imbalances - those who welcome a relatively larger number of students from abroad than the number of their nationals that they send abroad, like Austria and Belgium - tend to turn the prohibition of price discrimination through the adoption of quantitative quotas.

In line with the Bologna philosophy we propose to move from a system where the local public authorities are responsible for the financing of the studies supplied on their territory to a system where those authorities are responsible for the financing of the studies demanded by the students from their territory. To fix the ideas - see Figure 5 above - we may consider as students from a territory those who have obtained their previous degree (high shool, bachelor) on that territory after spending some years of studies in that territory.

Financing the students can take the form of issuing two-part portable vouchers.

We complete that mechanism with the suggestion of a system of compensation for the country which issued the vouchers, in case of further international career of the graduate.

\subsection{A first part to cover the real cost of studies}

The first part of the voucher is designed to finance the real cost of studies at home or abroad.

The student who wants to enroll, say for the first year of a master program in math's, applies for a voucher for that year and field of studies. The competent authority issues the voucher possibly subject to some conditions - see below and the student gives the voucher to the higher education institution where he or she has been accepted; that institution presents the voucher to the issuing authority and receives the corresponding amount of money. Possibly an international clearing system is set up like the inter-cantonal clearing in Switzerland - see below appendix section 10.1.

Table 2, based on actual subsidies in the French-speaking Community of Belgium, provides an illustration of what could be that first part of the voucher. 


\begin{tabular}{|c|c|}
\hline University Higher Education & $\begin{array}{l}\text { Euros per } \\
\text { student }\end{array}$ \\
\hline $\begin{array}{l}\text { Bachelor or Master degree in philosophy; theology; languages and literature; history, arts } \\
\text { and archaeology; architecture and urbanism; information and communication; political } \\
\text { sciences and sociology; law; criminology; economics and management; education and } \\
\text { psychology }\end{array}$ & 5.597 \\
\hline $\begin{array}{l}\text { First or second year of Bachelor degree in medical sciences; veterinary medicine; } \\
\text { dentistry; agricultural engineering; engineering; Bachelor or Master degree in arts or arts } \\
\text { sciences }\end{array}$ & 11.195 \\
\hline $\begin{array}{l}\text { Third year of Bachelor or Master degree in medical sciences; veterinary medicine; } \\
\text { dentistry; natural sciences; agricultural engineering; engineering. }\end{array}$ & 16.792 \\
\hline \multicolumn{2}{|l|}{ Non-University Higher Education } \\
\hline Economics (3 year-professional bachelor degree) & 4.665 \\
\hline Economics (other degrees), technology (3 year-professional bachelor degree) & 5.132 \\
\hline Agriculture (3 year-professional bachelor degree), social sciences & 5.365 \\
\hline Engineering & 5.598 \\
\hline Interpreters and translators & 6.765 \\
\hline Health sciences & 6.998 \\
\hline
\end{tabular}

Table 2 - Estimates of the first part voucher value in EUROS. Source: Gérard and Vandenberghe (2007b). Estimates by field of studies, based on the 2005-2006 budget of the French-speaking Community of Belgium for the variable part of the financing.

\subsection{Subject to some conditions, especially of recognized quality}

It is up to the issuing authority to decide on the number of vouchers supplied for a given field and year.

The French government may, for instance, organize a competition for a predetermined number of vouchers in veterinary medicine. Applicants who fail to get the voucher can still be accepted by schools but then at a (high) price covering the real cost of the studies, either at home or abroad. Alternatively the schools may decide not to accept those unfunded students or, possibly, provisions in the international agreement organizing the system, may compel the schools to reject those applicants. In that latter case, partner countries help France enforcing its numerus clausus - the issue of a limited number of vouchers. Then indeed French students - the most likely to practice in France after completing their studies - no longer have the opportunity to overcome that quantitative limit deemed to be justified by the needs for a given profession. ${ }^{1}$

The use of the vouchers should also be limited to schools whose quality has been guaranteed or certified. That might be organized through a process of mu-

\footnotetext{
${ }^{1}$ In this paper, we do not question the reason why a given country decides to limit the access to a given field of studies; that decision is hold as an exogenous component of the setting.
} 
tual recognition - a school agreed by local domestic authorities is automatically agreed by partner countries - or through a process of certification by private or public agencies, like the Equis certification for business schools.

\subsection{A second part to support student's life}

The other part of the voucher is designed for supporting the cost of living. It may consist of a fixed amount of money or can be modulated depending on a series of parameters.

Let us mention some of them: the place the students will have to live, the belonging of the student to a targeted group - ethnic minority, immigrant, poor family, in intellectual or money terms -, the type of studies he or she intends to follow - that part of the voucher can be used to provide the students with incentives to undertake studies for which there is a social need not recognized by a high salary, like teacher or professor in secondary schools, the composition of the student's family like he or she having dependents.

The modularity of that part of the voucher is illustrated by the example of Norway in appendix section 10.2. below. In any case it makes it an interesting tool for introducing equity or fairness elements in the way student's life is financed. However we know that equity goals in education should gain to be met earlier in the education process - Woessmann (2006), Vandenberghe (2007), Heckman and Carneiro (2003).

\subsection{Grant, loan or a mix}

The voucher can take the form of a grant from the authorities of the country of origin, or of a (contingent) loan ${ }^{2}$ from those authorities or from a bank with possibly those authorities providing public collaterals ${ }^{3}$, or of a mix of a grant and a loan - see the case of Australia in appendix section 10.3. It is up to the domestic authorities to decide.

Nevertheless one can show that as long as most students going abroad come back home after completing their studies and then spend their career in their country of origin - in today Europe, except for sweet heart reasons most students go back home after their studies, the many reasons for that can be summarized through the concept of attachment to home, see Mansoorian and Myers (1993) - grants might be a sustainable solution - see Gérard (2007 and below).

\footnotetext{
${ }^{2}$ A loan is said 'contingent' when its charge depends on characteristics of the graduate, like his or her income; in that latter case the loan is said 'income contingent'. Since in this paper, the loan may be income contingent but does not need to be, we put 'contingent' between parentheses.

${ }^{3}$ Those loans, especially when income contingent, present a high degree of risk; therefore, especially in the European context, the fair operation of the system calls for collaterals provided by the public sector.
} 


\subsection{Completed with a compensation for the country of origin in case of international career of the graduate}

If mobility of graduates goes up, the device above can no longer be sustainable and inefficiencies may appear through externalities: a country $x$ finances higher education of a person originally resident of that country, either in country $x$ or in country $y$, but that education will eventually profit to country $z$, where the graduate will work and pay taxes. In that latter case, a compensation of the origin country, that which has issued the vouchers and thus financed the human capital of the graduate, might be considered. It may consist in turning vouchers from grants to loans, possibly income contingent - Ederveen and Thissen (2008) also shows that increased mobility calls for an individualization of higher education financing - or in imposing a tax on graduates working abroad; that tax looks as a Bhagwati tax - see Bhagwati (1976), Wilson (2008).

We show later in the paper that the combination of a system of vouchers and a compensation for the issuing country in case of further international career of the graduate is a substitute for a centralized efficient design. Notice that, provided that the charge of the loan or of the Bhagwati tax provides the debtor with a credit against his or her local tax liabilities, it is equivalent to have those charges paid by that individual or by the local authorities.

Of course an alternative solution is to have the vouchers granted by a central agency operated at EU or Bologna area level. That device however does not seem to be compatible with the subsidiarity principle: clearly a decentralized solution exists which can allow each member state to decide on the high of the vouchers.

\section{The model}

Thereafter we successively depict the demand and supply of credits and the equilibrium of the market for credits, assuming that a degree is granted after successful completion of a given number of credits. For example, in the Bologna area, a bachelor degree may need 180 credits, and a master degree, a further 120 credits. The equilibrium might result from the use of a market clearing tuition fee or be the minimum of supply and demand if no such pricing mechanism is at work. More generally we consider a world with two (local) jurisdictions $i$ and $j$ called the jurisdictions or the countries, and a federal or central jurisdiction named the centre. The executives of the jurisdictions are governments; the executive of the centre is a central agency like the European commission.

\subsection{The demand for credits}

The representative student of a given jurisdiction $i$ decides on the number of credits (in the Bologna area they are called ECTS for Exchange Credits Transfer System) that he or she wants to get at home and abroad, $n_{i i}$ and $n_{i j}$ respectively.

The money return on credits obtained at home is $\underline{m} f\left(n_{i i}\right)$ if the student 
decides to work at home after completing his or her studies and $\widehat{m} f\left(n_{i i}\right)$ if he or she migrates to the other jurisdiction after studies. The probability to work at home, for the entire career, is $\rho_{h}$; that probability is totally exogenous. Thus, in average, credits obtained at home pay $m^{\prime} f\left(n_{i i}\right)=\left[\rho_{h} \underline{m}+\left(1-\rho_{h}\right) \widehat{m}\right] f\left(n_{i i}\right)$ per credit. The corresponding return on credits obtained abroad are $\bar{m} f\left(n_{i j}\right)$ if the degree is then used in the country of origin, an event of probability $\rho_{f}$, and $\widehat{m} f\left(n_{i j}\right)$ if the degree is valued in the country of studies, i.e. the student remains abroad after completing his or her degree; in average the return per credit abroad is $\widetilde{m} f\left(n_{i j}\right)=\left[\rho_{f} \bar{m}+\left(1-\rho_{f}\right) \widehat{m}\right] f\left(n_{i j}\right)$.

We assume that $\bar{m} \geq \widehat{m} \geq \underline{m}$ : studies abroad are especially valued in the origin country through a high money reward for foreign credits; ex-foreign students are also appreciated because they bring a touch of openness in the country. We assume $f^{\prime}>0$ and $f^{\prime \prime}<0$.

However getting credits has a cost: a sacrifice in terms of unskilled wage $w_{i}$, possibly a tuition fee $p_{i i}$ or $p_{i j}$ to be paid at home or abroad and, in cases of studies abroad, an extra cost in terms of, say, acquisition of a foreign language, accommodation and transportation to be paid from the home jurisdiction $q\left(n_{i j}\right)$, $q^{\prime}>0, q^{\prime \prime} \geqslant 0$. We name that latter cost mobility cost.

Moreover, in line with the proposition issued above, the student may receive a voucher per credit - then we assume $p=0$. The voucher will be used to cover the actual cost of studies so that it does not enter the set of parameters of the utility function of the student - the student simply channels the voucher. If the voucher also covers the extra costs $q\left(n_{i j}\right)$, that parameter disappears from the utility function when covered by the voucher; we indicate that possibility by setting a $\delta_{q}$ before the extra costs parameter $-\delta_{q}=0$ if the voucher covers extra costs, otherwise $\delta_{q}=1$.

Vouchers are either provided for free or sold at a price $p_{i i}^{v}$ or $p_{i j}^{v}$ where the subscript first indicates the issuing country - in our case country $i$ - and second whether the voucher is for use in the domestic $i$ country or in the foreign country $j$.

Although the mobile graduate may possibly be required to compensate its country of origin, that device doesn't affect his or her choice since we assume that the compensation might be credited against the local tax liabilities - this is supposed to be a provision of the treaty enforcing the system.

Given those parameters, the individual maximizes his or her utility function supposed to be additive separable ${ }^{4}$

$$
\begin{aligned}
U_{i} & =m^{\prime} f\left(n_{i i}\right)+\widetilde{m} f\left(n_{i j}\right)-w_{i}\left(n_{i i}+n_{i j}\right)-p_{i i} n_{i i}-p_{i j} n_{i j}-\delta_{q} q\left(n_{i j}\right) \\
& -p_{i i}^{v} n_{i i}-p_{i j}^{v} n_{i j}
\end{aligned}
$$

From the first order conditions of that maximization,

$$
\begin{aligned}
& m^{\prime} f^{\prime}\left(n_{i i}\right)=w_{i}+p_{i i}+p_{i i}^{v} \\
& \widetilde{m} f^{\prime}\left(n_{i j}\right)=w_{i}+p_{i j}+\delta_{q} q^{\prime}\left(n_{i j}\right)+p_{i j}^{v}
\end{aligned}
$$

\footnotetext{
${ }^{4} \mathrm{~A}$ more general specification could substitute $F\left(n_{i i}, n_{i j}\right)$ for $m^{\prime} f\left(n_{i i}\right)+\widetilde{m} f\left(n_{i j}\right)$.
} 
we obtain the equilibrium values of $n_{i i}$ and $n_{i j}$ desired by the prospective student of country $i$,

$$
\begin{aligned}
& n_{i i}^{d}=n_{i i}^{d}\left(p_{i i}, m^{\prime}, \rho_{h}, v_{i i}, p_{i i}^{v}\right) \\
& n_{i j}^{d}=n_{i j}^{d}\left(p_{i j}, \widetilde{m}, \rho_{f}, \delta_{q}, v_{i j}, p_{i j}^{v}\right)
\end{aligned}
$$

which form the demand functions, or demand system, for credits.

Second order condition holds since $f "-\delta_{q} q "<0$.

Let us highlight the reasoning above and specify $f(n)$ as $\ln n$ and $q(n)$ as $q n$. Then the demand functions become

$$
\begin{aligned}
n_{i i}^{d} & =\frac{m^{\prime}}{w_{i}+p_{i i}+p_{i i}^{v}} \\
n_{i j}^{d} & =\frac{\widetilde{m}}{w_{i}+p_{i j}+\delta_{q} q+p_{i j}^{v}}
\end{aligned}
$$

In the sequel of the paper we will make an extensive use of that specification of the demand functions as well as of the hypothesis that the countries are symmetric; in line with that latter hypothesis we will drop subscripts $i$ and $j$ and use $h$ and $f$ instead of $i i$ (viz. $j j$ ) and $i j$ (viz. $j i$ ) respectively.

\subsection{The supply of credits}

We assume that universities are public in the sense that they make own the objective of the government of their country. Therefore we assume that the supply of credits is decided by the government, which maximizes a Social Welfare Function defined on the future contribution to GDP of graduates educated at home or abroad, who will be resident of the jurisdiction, net of the sacrifice in terms of immediate contribution to GDP involved by the studies of the residents, of the cost of the public funds levied to finance the production of credits and of the costs related to studies abroad, but grossed with the tuition fee and the net inflow of possible compensations.

Thus social welfare functions are such that

$$
\begin{aligned}
W_{i} & =\underline{\theta} \rho f\left(n_{i i}\right)+\bar{\theta} \rho f\left(n_{i j}\right)-w_{i}\left(n_{i i}+n_{i j}\right)-p_{i j} n_{i j}-q\left(n_{i j}\right) \\
& +\widehat{\theta}(1-\rho) f\left(n_{j i}\right)+\widehat{\theta}(1-\rho) f\left(n_{j j}\right)+p_{j i} n_{j i}-c\left(n_{i i}+n_{j i}\right) \\
& -\left(v_{i j}-\delta \tau_{i j}^{j}\right) n_{i j}+\delta \tau_{i i}^{j} n_{i i}-\delta \tau_{j i}^{i} n_{j i}-\delta \tau_{j j}^{i} n_{j j}
\end{aligned}
$$

and similarly for $W_{j}$.

In that equation $\tau$ represents the compensation transferred from a country to another, either because the graduate working abroad has seen his or her voucher turned into a loan, or because a Bhagwati tax is due, both being deductible against local tax liabilities; the first subscript refers to the origin country of the student, the second one to the country where he studied, while the superscript indicates the paying jurisdiction - the foreign jurisdiction where the graduate works; $\delta=1$ if that compensation system is at work, $\delta=0$ otherwise. 
We allow for $\theta$ different from $m$, by which is meant that the social return on higher education might be different from the private one. ${ }^{5}$ Finally $c\left(n_{i i}+n_{j i}\right)$ is the cost for the public sector of providing higher education, including the efficiency cost of turning, say, a lump sum tax into a subsidy to universities see Laffont-Tirole (1993); we assume $c^{\prime}, c ">0$. Without loss of generality we can linearize that latter function and set $c\left(n_{i i}+n_{j i}\right)=c n_{i i}+c n_{j i}$; we assume $c$ identical across countries. The other parameters have been defined above.

First order conditions of the maximization of $W_{i}$ are,

$$
\begin{aligned}
\underline{\theta} \rho f^{\prime}\left(n_{i i}\right) & =w_{i}+c-\delta \tau_{i i}^{j} \\
\bar{\theta} \rho f^{\prime}\left(n_{i j}\right) & =w_{i}+p_{i j}+q+v_{i j}-\delta \tau_{i j}^{j} \\
\widehat{\theta}(1-\rho) f^{\prime}\left(n_{j i}\right) & =c-p_{j i}+\delta \tau_{j i}^{i}
\end{aligned}
$$

However all those conditions are not required to hold simultaneously. As we will seen later on, the first and last conditions have to hold under the current system based on the Production Principle, but then there are no voucher nor compensation $(\delta=0)$; the first and second conditions have to hold under the alternative Origin Principle where vouchers are considered, and of course when we extend the model assuming an increased mobility of graduates and introducing compensations across countries.

Second order condition is satisfied since $f^{\prime \prime}<0$.

For illustrative purposes, suppose again that $f(n)=\ln (n)$. Then,

$$
\begin{aligned}
n_{i i}^{s} & =\frac{\underline{\theta} \rho}{w_{i}+c-\delta \tau_{i i}^{j}} \\
n_{i j}^{s} & =\frac{\bar{\theta} \rho}{w_{i}+p_{i j}+q+v_{i j}-\delta \tau_{i j}^{j}} \\
n_{j i}^{s} & =\frac{\widehat{\theta}(1-\rho)}{c-p_{j i}-\delta \tau_{j i}^{i}}
\end{aligned}
$$

We can now consider four relevant cases separately. The first one assumes that the financing of higher education is centralized: a centre has been set up at the level of the Bologna area and is in charge of financing higher education; this is the benchmark efficient case. The second one corresponds to the current application of the Production Principle. The third one refers to the application of the alternative Origin Principle and introduces the voucher $\left(p=0, v=c+\delta_{q} q\right.$, $\delta=0)$. Finally, the fourth case combines voucher and some refund in case of career abroad $(\delta=1)$, either under the form of a grant turned into a (contingent) loan or of a Bhagwati tax; that case is especially relevant when the mobility of graduates becomes important.

\footnotetext{
${ }^{5}$ It is often considered that the social return on higher education exceeds the private one, however authors like Jacobs and van der Ploeg (2006) argue that $\theta$ does not exceed $m$. Therefore we only assume that $\theta$ may differ from $m$.
} 


\section{A centralized device}

Let us start with the centralized device: a centre has been set up at the level of the Bologna area and is in charge of financing higher education. That setting is an interesting benchmark where spillover effects have been internalized, and which therefore makes sense for an integrated area where the degree of mobility of students and graduates is high; however that setting is in opposition with the subsidiarity principle at the root of the functioning of the European Union.

Since, in this centralized device, there is actually a single jurisdiction with a single financing authority, the explicit use of vouchers and compensation do not justify - in other words vouchers should be just a way to channel funds from the central agency to the schools - except for the part of vouchers which possibly covers the extra costs related to studying abroad, $\delta_{q}=0$. Then, demand for credits is, from equation (4) and assuming symmetry, in both $i$ and $j$,

$$
\begin{aligned}
n_{h}^{d} & =\frac{m^{\prime}}{w+p_{h}} \\
n_{f}^{d} & =\frac{\widetilde{m}}{w+p_{f}+\delta_{q} q}
\end{aligned}
$$

Since the centre jointly maximizes $W_{i}$ and $W_{j}$, the supply of credits is, from adapting equation $(7)^{6}$, again in both $i$ and $j$,

$$
\begin{aligned}
& n_{h}^{s}=\frac{\theta^{\prime}}{w+c} \\
& n_{f}^{s}=\frac{\widetilde{\theta}}{w+q+c}
\end{aligned}
$$

\subsection{Price equilibrium}

The equilibrium between supply and demand for credits can be reached through a system of tuition fees. Using the latter two sets of equations, we obtain, first assuming $\delta_{q}=1$, the following two efficient tuition fees

$$
\begin{aligned}
& p_{h}^{C}=\frac{m^{\prime}-\theta^{\prime}}{\theta^{\prime}} w+\frac{m^{\prime}}{\theta^{\prime}} c \\
& p_{f}^{C}=\frac{\widetilde{m}-\widetilde{\theta}}{\widetilde{\theta}}(w+q)+\frac{\widetilde{m}}{\widetilde{\theta}} c
\end{aligned}
$$

Especially, if private and social returns coincide,

$$
p_{f}^{C}=p_{h}^{C}=c
$$

\footnotetext{
${ }^{6}$ Maximizing $W_{i}+W_{j}$ with respect to $n_{i i}$ and $n_{i j}$ implies$$
\underline{\theta} \rho f^{\prime}\left(n_{i i}\right)+\widehat{\theta}(1-\rho) f^{\prime}\left(n_{i i}\right)=\theta^{\prime} f^{\prime}\left(n_{i i}\right)=w_{i}+c
$$$$
\bar{\theta} \rho f^{\prime}\left(n_{i j}\right)+\widehat{\theta}(1-\rho) f^{\prime}\left(n_{i j}\right)=\widetilde{\theta} f^{\prime}\left(n_{i j}\right)=w_{i}+q+c
$$ 
and both domestic and foreign students are charged a tuition fee equal to the marginal cost of studies. Otherwise the tuition fee will be smaller if the social return exceeds the private one, and conversely, the tuition fee will be larger if the private return exceeds the social one. Not irrelevant at all is the case where a degree obtained abroad is overvalued by the labor market, so that $\widetilde{m}>\widetilde{\theta}$ although $m^{\prime}=\theta^{\prime}$; then the model justifies charging a higher tuition fee to foreign students: the local university sells them the rent represented by their diploma.

If $\delta_{q}=0$, the tuition fee for studies abroad becomes

$$
p_{f}^{q}=p_{f}^{C}+q
$$

so that the socialization of extra costs has been offset.

\subsection{Non-price equilibrium}

We know that public prices may obey other goals than efficiency, like equity, understood as a general and fair access to higher education. Then, again for $\delta_{q}=1$

$$
\begin{aligned}
& p_{h} \leq \frac{m^{\prime}-\theta^{\prime}}{\theta^{\prime}} w+\frac{m^{\prime}}{\theta^{\prime}} c \\
& p_{f} \leq \frac{\widetilde{m}-\widetilde{\theta}}{\widetilde{\theta}}(w+q)+\frac{\widetilde{m}}{\widetilde{\theta}} c
\end{aligned}
$$

and effective amounts of credits will correspond to the minimum of demand and supply, thus here to supply - see equation (9). Since the supply of credits is not a function of the tuition fee in this model, the effective number of credits is the same under both the price and the non-price equilibria.

Therefore, in the sequel of the paper, we term the equilibrium prices defined by equation (10) the efficient prices or the efficient tuition fees, and the amounts of credits defined by equation (9) the efficient numbers of credits.

\section{The current system: applying the Production Principle}

Most countries of the Bologna area, and thus most member states of the European Union, apply the Production Principle, by which is meant that the local government finances the schools of higher education located in its territory where they produce an enriched human capital. Therefore higher education of the foreign students is financed by the taxpayers of the host country.

We assume that the governments directly compensate the schools for the cost of the studies except for a small tuition fee that students might be required to pay by their own; there is no voucher nor contingent loan or interjurisdictional compensation in that case although, as in the centralized device, such 
mechanisms could be introduced without altering the results. Nevertheless we still compute the prices equating supply and demand, even if they are no longer efficient.

In that case the demand of credits is still provided by equation (4) rewritten

$$
\begin{aligned}
n_{i i}^{d} & =\frac{m^{\prime}}{w_{i}+p_{i i}} \\
n_{i j}^{d} & =\frac{\widetilde{m}}{w_{i}+p_{i j}+q}
\end{aligned}
$$

while the local government decides on the supply of credits to local and foreign students, $n_{i i}$ and $n_{j i}{ }^{7}$, so that, given the first and third lines of equation (7),

$$
\begin{aligned}
n_{i i}^{s} & =\frac{\underline{\theta} \rho_{h}}{w_{i}+c} \\
n_{j i}^{s} & =\frac{\widehat{\theta}\left(1-\rho_{f}\right)}{c-p_{j i}}
\end{aligned}
$$

Comparison of equations (9) and (15), on the one hand, and of equations (8) and (14), on the other hand, immediately reveals that the supply function for domestic credits has shifted leftward while the demand line remained unchanged. Consequently equilibrium price has departed from its value according to equation (10), becoming inefficiently high ${ }^{8}$ and involving too few credits obtained at home by domestic students; especially, if social and private returns on higher education are equal, the equilibrium price for domestic credits now exceeds the marginal cost of studies. The intuition behind that reasoning is that local government only takes into account the students who remain at home after their studies. Termed otherwise, the government corrects its supply of credits for the expected outflow of graduates.

Conversely the equilibrium price for credits abroad becomes smaller than the efficient price computed in the previous section. ${ }^{9}$ This is because the local

\footnotetext{
${ }^{7}$ That latter amount can be viewed as a quota of foreign students.

${ }^{8}$ We observe

$$
p_{h}^{P}=\frac{m^{\prime}-\underline{\theta} \rho_{h}}{\underline{\theta} \rho_{h}} w+\frac{m^{\prime}}{\underline{\theta} \rho_{h}} c>\frac{m^{\prime}-\theta^{\prime}}{\theta^{\prime}} w+\frac{m^{\prime}}{\theta^{\prime}} c=p_{h}^{C}
$$

as long as $\rho_{h}<1$.

${ }^{9}$ We have

$$
p_{f}^{P}=\frac{\widetilde{m}}{\widetilde{m}+\widehat{\theta}\left(1-\rho_{f}\right)} c-\frac{\widehat{\theta}\left(1-\rho_{f}\right)}{\widetilde{m}+\widehat{\theta}\left(1-\rho_{f}\right)}(w+q)<\frac{\widetilde{m}-\widetilde{\theta}}{\widetilde{\theta}}(w+q)+\frac{\widetilde{m}}{\widetilde{\theta}} c=p_{f}^{*}
$$

as long as $(\bar{\theta}-\bar{m}) \rho_{f}-\bar{m}\left(1-\rho_{f}\right)<0$; especially, if $\bar{\theta}-\bar{m}=0$, that condition turns out to be $\rho_{f}<1$.

Notice that, for students expected not to return home, the tuition fee derived above becomes

$$
p_{f}=\frac{\widehat{m}}{\widehat{\theta}+\widehat{m}} c-\frac{\widehat{\theta}}{\widehat{\theta}+\widehat{m}}(w+q)
$$

or, if $\widehat{\theta}=\widehat{m}$,

$$
p_{f}=\frac{c-w-q}{2}
$$
}


government only balances the future contribution to local GDP of the foreign students expected to remain in its country after completing their studies, with their net cost for that sole country, $c-p_{j i}$, thus disregarding the costs in terms of lost contribution to the GDP, $w$, and extra costs $q$, supported by the other country. In that case the equilibrium price is inefficiently low and even below the marginal cost of studies and below the equilibrium tuition charged to local students.

Anyway, if the tuition fee charged to both groups of students is a comprised between zero and the efficient value $p^{C}$, defined in the centralized case, thus as long as $p_{k}=a \in\left[0, p_{k}^{C}\right], k=f, h$, there are too few students getting credits at home and too few students as well getting credits abroad, provided that, for the latter group, supposing $c-a>0$,

$$
\rho_{f}>\frac{\widehat{\theta}(w+q+a)}{\widehat{\theta}(w+q+a)+\bar{\theta}(c-a)}
$$

\section{An alternative system (I): applying the Origin Principle using vouchers}

Suppose now that the local government no longer finances schools of higher education located in its territory but students from its territory who want to study either at home or abroad. This is what we call applying the Origin Principle.

Then, unlike in the previous case, the government of country $i$ now decides on $n_{i i}$ and $n_{i j},{ }^{10}$ To those students the government gives a voucher corresponding to the true cost $c$ of studies plus possibly an amount covering extra costs $q$ related to studies abroad $-v_{i i}=c, v_{i j}=c+\left(1-\delta_{q}\right) q$. The vouchers are provided for free - we relax that assumption at the end of the section. Demand for credits is still given by equation (4) now rewritten,

$$
\begin{aligned}
n_{i i}^{d} & =\frac{m^{\prime}}{w_{i}} \\
n_{i j}^{d} & =\frac{\tilde{m}}{w_{i}+\delta_{q} q}
\end{aligned}
$$

while the supply of credits is provided by the first two lines of equation (7) notice that $W_{i}$ is now maximized w.r.t. $n_{i i}$ and $n_{i j}$ instead of $n_{i i}$ and $n_{j i}$,

$$
\begin{aligned}
n_{i i}^{s} & =\frac{\underline{\theta} \rho}{w_{i}+c} \\
n_{i j}^{s} & =\frac{\bar{\theta} \rho}{w_{i}+q+c}
\end{aligned}
$$

which can be regarded as a strategic brain drain price to attract bright foreign students.

On the contrary, if foreign students are expected to leave the country after their degree, then the equilibrium tuition fee is $p_{f}^{P}=c$.

${ }^{10}$ The sum of those figures can be understood as a numerus clausus enforced across borders. 
From the comparison of those two equations it turns out that the effective amounts of credits are given by the latter.

Now, that outcome should be compared with its counterparts under the benchmark centralized case and the application of the Production Principle under similar condition, thus assuming that no tuition fee is charged to students. Then we have,

\begin{tabular}{|c|c|c|c|}
\hline & Centralization & Production & Origin \\
\hline$n_{i i}^{s}$ & $\frac{\theta^{\prime}}{w+c}$ & $\frac{\underline{\theta} \rho_{h}}{w+c}$ & $\frac{\underline{\theta} \rho_{h}}{w+c}$ \\
\hline$n_{i j}^{s}$ & $\frac{\widetilde{\theta}}{w+q+c}$ & $\frac{\widehat{\theta}\left(1-\rho_{f}\right)}{c}$ & $\frac{\bar{\theta} \rho_{f}}{w+q+c}$ \\
\hline
\end{tabular}

From the inspection of that table we conclude that, in the absence of tuition fee supported by the students, (1) the amount of credits obtained at home is the same under the Origin Principle as under the Production Principle, and is inefficiently low except if $\rho=1$; (2) the amount of credits obtained abroad is larger under the Origin Principle than under the Production Principle, provided that

$$
\rho_{f}>\frac{\widehat{\theta}(w+q+c)}{\widehat{\theta}(w+q+c)+\bar{\theta} c} \equiv \underline{\rho}_{f}
$$

and, moreover, that amount remains inefficiently low except of $\rho=1$.

We can then issue the following proposition:

Proposition 1 In the absence of tuition fee charged to the students, a system of financing higher education students based on the Origin Principle is more efficient than a system of financing schools of higher education based on the Production Principle, provided that the probability of returning home after completing the studies and then spending career at home, is larger than some threshold.

Two remarks usefully complete the development above and the proposition. First, one can easily show that, at least in a symmetric world, the two countries gain from adopting the reform. Indeed the condition for both countries to gain then turns out to be, from equation (5)

$$
\tilde{\theta}\left(\ln n_{f}^{O}-\ln n_{f}^{P}\right)-(w+q+c)\left(n_{f}^{O}-n_{f}^{P}\right)>0
$$

where superscripts $O$ and $P$ refer to the Origin and Production principles respectively. That condition might be approximated by

$$
2 \tilde{\theta} \frac{n_{f}^{O}-n_{f}^{P}}{n_{f}^{O}+n_{f}^{P}}-(w+q+c)\left(n_{f}^{O}-n_{f}^{P}\right)>0
$$

When $\rho_{f}>\underline{\rho}_{f}, n_{f}^{O}-n_{f}^{P}>0$. Then the condition reduces to

$$
\frac{\tilde{\theta}}{(w+q+c)}>\frac{n_{f}^{O}+n_{f}^{P}}{2}
$$


By equation (9) this is equivalent to

$$
n_{f}^{C}>\frac{n_{f}^{O}+n_{f}^{P}}{2}
$$

where superscript $C$ refers to the centralized device. That condition is satisfied since $n_{f}^{C}$ is larger than both $n_{f}^{O}$ and $n_{f}^{P}$.

Otherwise, in that system, the vouchers could be not provided for free but charged prices $p_{h}^{v}$ and $p_{f}^{v}$ respectively. An extreme solution could be to have those latter prices equalizing supply and demand for credits at home and abroad. Then using equations (4) and (18) again, those prices solve

$$
\begin{aligned}
& n_{i i}^{d}=\frac{m^{\prime}}{w_{i}+p_{h}^{v}}=\frac{\underline{\theta} \rho}{w_{i}+c}=n_{i i}^{s} \\
& n_{i j}^{d}=\frac{\widetilde{m}}{w_{i}+p_{f}^{v}+\delta_{q} q}=\frac{\bar{\theta} \rho}{w_{i}+c+q}=n_{i j}^{s}
\end{aligned}
$$

However those prices are inefficient for the same reason as the equilibrium tuition fees under the Production Principle - external effects are not taken into account in the supply functions.

\section{An alternative system (II): when mobility of graduates increases, both the origin and des- tination countries need to contribute}

The system examined in the previous section is more efficient than the current one as long as mobility after completion of studies remains below some threshold. In other terms, if $\rho_{f}$ become smaller than $\underline{\rho}_{f}$ provided by equation (19), the system of vouchers provided by the country of origin is no longer more efficient than the current one based on the Production Principle.

Let us now investigate how that system can be completed to be relevant for a world where the mobility of graduates increases. The ultimate goal of the Bologna process can be viewed indeed as the creation of a European-wide labor market. Therefore, let us reinterpret $1-\rho_{k}, k=h, f$ as the probability for a graduate that the other country becomes his or her country of destination: he or she will spend his or her career in that country. Equivalently $1-\rho_{k}$ represents the fraction of the career time spent outside the country of origin of the graduate.

Now let us introduce the following institutional device: if a graduate does not spend his or her career time in his or her country of origin, he or she has to compensate that country for the financing of his or her studies, possibly pro rata temporis. In practice, that means that either the voucher, initially granted, is turned into a loan, possibly a contingent loan, and that the graduate has to pay some amount for each year spent outside his or her country of origin, or 
that the graduate has to pay an annual compensatory exit tax - in this case a Bhagwati tax - to his or her country of origin. The payment can be done either by the graduate or by the government of the country where he or she works; to guarantee that those two mechanisms are equivalent, we assume that the graduate benefits of a tax credit against his or her tax liabilities in the destination country for the amounts paid to his or her country of origin.

Under that extended institutional design, the equilibrium numbers of credits become, by equation (7),

$$
\begin{aligned}
n_{i i}^{O D} & =\frac{\underline{\theta} \rho}{w_{i}+c-\tau_{i i}^{j}} \\
n_{i j}^{O D} & =\frac{\bar{\theta} \rho}{w_{i}+q+c-\tau_{i j}^{j}}
\end{aligned}
$$

where superscript $O D$ refers to the implication of both the origin and destinations countries. Two interesting results then appear.

\subsection{More credits at home and abroad}

Comparison of equations (25) and (18) first reveals that the number of credits permitted to resident students, and thus of vouchers provided to them, is now larger; this is typically due to the compensation of the externality. It turns out that the measure lowers the threshold $\underline{\rho}_{f}$ provided by (19) and thus makes the use of the Origin Principle more likely to be more efficient than the current Production Principle. Indeed the condition for the Origin Principle being superior - or for $n_{i j}^{O}$ being larger than $n_{i j}^{P}$ - becomes,

$$
\rho>\frac{\widehat{\theta}\left(w_{i}+q+c-\tau_{i j}\right)}{\widehat{\theta}\left(w_{i}+q+c-\tau_{i j}^{j}\right)+\bar{\theta} c} \equiv \underline{\rho *} f
$$

and

$$
\frac{d \underline{\rho *} f}{d \tau_{i j}^{j}} \propto-\hat{\theta} \bar{\theta} c s<0
$$

so that the threshold goes down when working abroad compels the graduate to compensate his or her country of origin for the financing of his or her higher education. That mechanism makes the system discussed in this paper, more likely to be more efficient than the current one, based on the Production Principle.

Therefore,

Proposition 2 In the absence of tuition fee charged to the students, a system of financing higher education students based on the Origin Principle is more likely to be more efficient than a system of financing schools of higher education based on the Production Principle, when coupled with a mechanism compelling the graduate working abroad, or his or her country of destination, to compensate his or her country of origin in proportion of his or her working time spent abroad. 


\subsection{Equivalence with centralization}

Finally we can compute the values of the compensation payment which ensure the equality between $n_{k}^{O D}$ and $n_{k}^{C}, k=h, f$.

Using equations (9) and (25) we obtain that $n_{k}^{O D}=n_{k}^{C}$ if

$$
\begin{aligned}
\tau_{i i} & =\frac{\hat{\theta}\left(1-\rho_{h}\right)}{\theta^{\prime}}(w+c) \\
\tau_{i j} & =\frac{\hat{\theta}\left(1-\rho_{f}\right)}{\tilde{\theta}}(w+q+c)
\end{aligned}
$$

It turns out that if the graduate working abroad is hold to compensate his or her country of origin, pro rata temporis, for the social value of the loss of domestic product $w$, the cost $c$ and the possible extra cost $q$ involved by his or her studies, then applying the Origin Principle described so far, generates the same quantity of studies abroad as that determined cooperatively or decided by a benevolent central authority.

Then,

Proposition 3 In the absence of tuition fee charged to the students, a system of financing higher education students based on the Origin Principle, when coupled with a mechanism compelling the graduate working abroad, or his or her country of destination, to compensate his or her country of origin for the social value, in proportion of his or her working time spent abroad, of the cost generated by his or her studies, might be equivalent to the cooperative joint determination of the quantity of studies or to that determination by a benevolent central authority.

\section{Summary and conclusion}

Though the Bologna process paves the way for a large international market for graduates, nothing has been provided regarding the financing of student mobility. Therefore, countries with the best schools will become more attractive for foreign students, but due to the mostly used mechanism for financing higher education, that quality will cost to the residents of the host country. In economic terms, countries with best higher education will provide the other countries with a positive externality and countries might be tempted to free ride their better quality neighbors, with the risk that such a process eventually downsizes the global quality of higher education.

Already, many students from France and possibly from The Netherlands are educated in Belgian higher education institutions at the expense of the Belgian taxpayer. In that sense France free rides Belgium; the same phenomenon appears between Germany and Austria, especially in medicine, and again the larger country free rides its smaller neighbor. That situation creates imbalances and involves the appearance of protectionist behaviors from the local governments, like the introduction of quotas, which is exactly the opposite of what the Bologna process aims. 
Therefore, in order to overcome those negative issues, we have suggested, except for students from developing countries, to transfer the responsibility for financing higher education from the host country, to the country of origin of the students.

The mechanism that we suggest and discuss consists for the origin country to provide his and her students with a two-part portable voucher. The first part of the voucher intends to cover the true cost of studies and might be regarded as a tuition fee voucher; it may be used in any higher education institution of a defined international area - say the EU or the Bologna area - provided it is used in the field of studies for which it is dedicated and in a school whose quality has been recognized by the country of origin, possibly through a network of certification. The second part of the voucher is dedicated to finance the cost of living at home or abroad, and can be called a student support voucher. That part might be modulated to take into account dissimilarities in costs of living, or to favour targeted groups of students or fields of studies, or still to compensate extra costs related to the family situation of the student. In short one can say that the second part of the voucher might be equity or fairness-oriented.

The combination of the two parts of the voucher makes it an interesting tool to monitor the choice of the studies, and thus of the careers, as well as to favour a more democratic access to higher education.

Vouchers can either be provided for free, or they can take the form of a loan, or of a mix of a grant and a loan. This is up to the origin government to take decision in that matter. However, as long as students going abroad come back home after the completion of their studies and then spend their career time in their country of origin, providing vouchers for free might be justified. In contrast, when the mobility of graduates increases, so that the market for graduates becomes Bologna-wide or EU-wide actually, completing the system of vouchers by turning them from grants to loans in proportion of the time spent working abroad or by introducing a system of Bhagwati tax to compensate the country of origin is more efficient. Its practicability will depend on the integration of the Bologna or otherwise defined area.

In the analytical part of the paper, we present a model and then use it to investigate four cases successively. In that model we consider two countries or jurisdictions and a federal or central jurisdiction named the centre. The executives of the jurisdictions are governments; the executive of the centre is a central agency like the European commission. ${ }^{11}$

The first case is centralization: higher education is decided and financed by the centre; this is an interesting benchmark where spill over effects have been internalized, and which therefore makes sense for an integrated area where the degree of mobility of students and graduates is high; however that setting is in opposition with the subsidiarity principle at the root of the functioning of the European Union.

In the second case, we fit the model to the characteristics of the current

\footnotetext{
${ }^{11}$ Most results are developed assuming symmetrc jurisdictions; therefore an extension of the exercise should be to investigate situations where countries are asymmeric.
} 
application of the Production Principle and show than the amounts of credits obtained abroad, but also at home, are too low.

When we move to the application of the Origin Principle, the amount of credits are higher and the outcome of the public financing of higher education becomes less inefficient, provided that the probability to come back home after completion of the studies and then to work in the country of origin, exceeds some threshold - that situation is consistent with today relative mobility of labor in the European Union and the Bologna area.

In the last case we show that such threshold goes down when the system of vouchers provided by the country of origin is coupled with a mechanism compelling the graduate working abroad, or his or her country of destination, to compensate his or her country of origin. That mechanism can take the form of turning the vouchers from grants to (contingent) loans pro rata temporis the fraction of the career spent abroad, or of paying a yearly Bhagwati tax. The issue of the compensation being paid either by the graduate or by the country of destination becomes irrelevant if the payment by the graduate may be credited against his or her local tax liabilities in the country of destination.

That mechanism, although apparently complex, is actually feasible. National practices by Switzerland, Norway and other Nordic countries, and Australia, presented in appendix, prefigure some aspects of our proposal and highlight the paper. Otherwise, interjurisdictional arrangements already exist, at least in Europe, in social security matters, which provide that the country of origin of a patient has to compensate the country where he or she has been hospitalized. And, last but not least, a mechanism of compensation of the origin club - that which provided the initial education of the player - by the series of destination ones - those who benefited from that education - applies for soccer players.

\section{References}

[1] Andersson, F. and Konrad, K. (2003) "Globalization and Risky HumanCapital Investment", International Tax and Public Finance, 10, pp. 211228.

[2] Aghion, P., Dewatripont, M., Hoxby, C., Mas-Colell, A. and Sapir, A. (2008) "Higher aspirations: An agenda for reforming European universities", blueprint, Bruegel, Brussels.

[3] Australian Government, Department of Education, Employment and Workplace Relations, going to uni - higher education for students in Australia, website (pages consulted on April 20, 2008) [on-line] http://www.goingtouni.gov.au.

[4] Bache, I. (2006) "The Europeanization of higher education: markets, politics or learning", Journal of Common Market Studies, 44, pp. 231-248.

[5] Barr, N. (1998), The Economics of the Welfare State, Oxford University Press, Oxford. 
[6] Beine, M. et al. (2001) "Brain drain and economic growth: theory and evidence", Journal of Development Economics, 64, pp. 275-289.

[7] Bhagwati, J. (1976) Taxing the Brain Drain, Volume 1: A Proposal and The Brain Drain and Taxation, Volume 2: Theory and Empirical Analysis, North Holland.

[8] Bhagwati, J. and Hamada, K. (1974) "The brain drain, international integration of markets for professionals and unemployment", Journal of Development Economics, 64, pp. 275-289.

[9] Buettner, T. and Schwager, R. (2004) "Regionale Verteilungseffekte der Hochschulfinanzierung und ihre Konsequenzen", in: W. Franz et al. (eds) Bildung 33, Wirtschaftswissenschaftliches Seminar Ottobeuren, Tubingen.

[10] Chevalier, C. and Gérard, M. (2008) "Financing higher education and student mobility across Europe", mimeo, Arpege/LSM/Fucam.

[11] Conférence Suisse des directeurs cantonaux de l'instruction publique, CDIP (1997) Accord intercantonal universitaire du 20 février 1997, BerneLausanne.

[12] Ederveen, S. and Thissen, L. (2008) "European coordination of higher education", in G. Gelauff, I. Grilo and A. Lejour, eds, Subsidiarity and Economic Reform in Europe, Springer, pp. 113-128 (chapter 7).

[13] Gérard, M. (2006a) "Enseignement supérieur et mobilité, l'interpellation du passager clandestine", in: M. Gérard and V. Vandenberghe (Eds). L'enseignement supérieur après Bologne, Reflets et Perspectives de la vie économique, 45(2), pp. 83-89.

[14] Gérard, M. (2006b) "Le financement des études supérieures transfrontalières", Revue d'Economie Politique, 116(6), pp. 789-796.

[15] Gérard, M., (2007), "Financing Bologna: which country will pay for foreign students?", Education Economics, 15(4), pp. 441 - 454.

[16] Gérard, M., (2008), "Higher Education, Mobility and the Subsidiarity Principle", in G. Gelauff, I. Grilo and A. Lejour, eds, Subsidiarity and Economic Reform in Europe, Springer, pp. 97-112 (chapter 6).

[17] Gérard, M. and V. Vandenberghe, (2007a), "Mobilité étudiante en Europe : une idée qui mérite mieux que des quotas", Regards Economiques, 54, Septembre.

[18] Gérard, M. and V. Vandenberghe, (2007b), "Financement de l'enseignement supérieur et mobilité du capital humain en Europe" in F. Docquier and F. Thys-Clément, éds., Education et Force de Travail, Rapport de la Commission 1 au 17ème Congrès des Economistes belges de langue française, Cifop, Charleroi. 
[19] Grubel, H. and Scott, A. D. (1966) "The international flow of human capital", American Economic Review,56, pp. 268-274.

[20] Heckman, J. and Carneiro, P. (2003) "Human Capital Policy", NBER wp 9495, NBER, Ma.

[21] Jacob, B. and F. van der Ploeg (2006) "Guide to reform of higher education: a European perspective", Economic Policy, 21, pp. 535-592.

[22] Jongbloed, B. and J. (2000) Vouchers for higher education? A survey of the literature Commissioned by the Hong Kong University Grants Committee, Center fot Higher Education Policy Studies.

[23] Justman, M. and Thisse, J.-F. (1997) "Implications of the mobility of skilled labor for local public funding of higher education", Economics Letters, 55, pp. 409-412.

[24] Justman, M. and Thisse, J.-F. (2000) "Local Public Funding of Higher Education when Skilled Labor is Imperfectly Mobile", International Tax and Public Finance, 7, pp. 247-258.

[25] Kemnitz, A. (2005) "Educational federalism and the quality effects of tuition fees", paper presented at the Conference on Higher Education, Multijurisdictionality and Globalization, Mons, 14-15 December.

[26] Laffont, J.-J. and Tirole, J. (1993) A Theory of Incentives in Procurement and Regulation, MIT Press, Cambridge, MA.

[27] Lanekassen, website http://www.lanekassen.no (pages consulted on April 25, 2008) [on-line].

[28] Levin, H. (1983), "Individual entitlements", in: H. Levin and H. Schütze (eds), Financing Recurrent Education, Sage, Beverly Hills.

[29] Levy, J. S. (2004), "Student finance schemes in Norway. A case study", study made for the UNESCO and published by the IIEP, Paris.

[30] Mansoorian, A. and Myers, G. (1993) "Attachment to home and efficient purchases of population in a fiscal externality economy", Journal of Public Economics, 52, pp. 117-132.

[31] Mechtenberg, L. and Strausz, R. (2006) "The Bologna Process: how student mobility affects multicultural skills and educational quality", paper presented at the Conference on Higher Education, Multijurisdictionality and Globalization, Mons, 14-15 December.

[32] Mechtenberg, L. and Strausz, R. (2008) "The Bologna Process: how student mobility affects multicultural skills and educational quality", International Tax and Public Finance, 15, pp. 109-130. 
[33] Nordic Council of Ministers (1996) Agreement on Admission to Higher Education of the 3 September 1996, Copenhagen.

[34] OECD (2007) Education at glance, OECD, Paris.

[35] Poutvaara, P. (2004a) "Educating Europe: should public education be financed with graduate taxes or income-contingent loans?", CESifo Economic Studies, 50(4), pp. 663-684.

[36] Poutvaara, P. (2004b) "Public education in an integrated Europe: studying to migrate and teaching to stay?", CESifo Working Paper No. 1369, CESifo, Munich, Germany.

[37] Poutvaara, P. and Kanniainen, V. (2000) "Why Invest in your Neighbor? Social Contract on Education Investment", International Tax and Public Finance, 7, pp. 547-563.

[38] Sapir, A. et al. (2003) An Agenda for a Growing Europe, Making the EU Economic System Deliver, European Commission, Brussels.

[39] Stark, O. et al. (1997) "A brain gain with a brain drain", Economics Letters, 55 pp. $227-234$.

[40] Stark, O. and Wang, Y. (2002) "Inducing human capital formation: migration as a substitute for Subsidies", Journal of Public Economics, 86, pp. $29-46$.

[41] Vandenberghe, V. (2007) "Family Income and Tertiary Education Attendance across the EU. An empirical assessment using sibling data", Case DP No 123, Case-Sticerd, LSE, London.

[42] Vandenberghe, V. and Debande, O. (2006) "Deferred and IncomeContingent Tuition Fees: an empirical assessment using Belgian, German and UK data", Education Economics, 15(4), pp. 421-440.

[43] Vandenberghe, V. and Debande, O. (2007) "Refinancing EU's Higher Education with Deferred and Income-Contingent Tuition Fees. An empirical assessment using Belgian, German and UK data", Case DP No 124, CaseSticerd, LSE, London.

[44] van der Ploeg, F. and Veugelers, R. (2007) "Higher education reform and the renewed Lisbon strategy: role of the member states and the European Commission" in G. Gelauff, I. Grilo and A. Lejour, eds, Subsidiarity and Economic Reform in Europe, Springer, pp. 65-96 (chapter 5).

[45] Woessmann, L. (2006) "Efficiency and Equity of European Education and Training Policies", CESifo wp 1779, CESifo, Munich.

[46] Wilson, J. (2008) "Taxing the Brain Drain: A Reassessment of the Bhagwati Proposal", Michigan State University, mimeo. 


\section{A Appendix: Some actual national practices}

Three national practices are documented thereafter. The inter-cantonal clearing system in Switzerland illustrates the feasibility of portable vouchers: a school in canton $y$, rather than presenting the voucher directly to the issuing government $x$, presents it to its own government which then introduces it in a clearing process.

The Norwegian mechanism of portable vouchers is a good illustration of the system we suggest, especially of its second part, but of the first part too as long as studies abroad are concerned - that system introduces references to quality requirement and the additional costs like those related to the acquisition of a foreign language. The examination of the Australian case completes our discussion of grants vs. loans.

\section{A.1 The Swiss system of inter-cantonal clearing}

Switzerland is a confederation of 26 cantons with large executive and legislative powers; various competencies are assigned to the cantons, shared between the cantons and the confederation or reserved to that latter. Competencies on higher education are among those divided between the confederation and the cantons; moreover a process of standardization of the whole education system is currently under way.

As in most federations a system of equalization, aiming at leveling intercantonal differences, is at work in Switzerland. Interestingly, it also applies to inter-cantonal mobility of students.

Since higher education is partly financed by cantons, a system of clearing has been set up which is called "Inter-cantonal University Agreement". It aims at creating a coordinated Swiss university policy; especially it guarantees access to university in accordance with the principle of equality of treatment of Swiss residents, and it fixes the compensation that debtor cantons have to pay to university cantons for students from their territory - see Conférence Suisse des directeurs cantonaux de l'instruction publique (1997). A debtor canton is a canton that has to pay a contribution to another canton: its outflow of students exceeds its inflow. A university canton is a canton that supports the cost of a university or of an equivalent institution located on its territory. The debtor cantons pay an annual contribution to the university cantons for the education of their resident students. The university cantons guarantee an equal access to all Swiss students whichever their canton of residence. Thanks to a system of clearing, debtor canton $x$ must only pay a contribution to university canton $y$ in line with the difference between outgoing students to canton $y$ and incoming students from that canton. If the difference is negative canton $x$ has nothing to pay to canton $y$.

Notice that next to cantons funded universities, Switzerland has federal schools of higher education like the federal polytechnic schools of Lausanne and Zurich. 
A clearing system is also at work among Nordic countries - see Nordic Council of Ministers (1996). It also aims at equalizing financial contributions to higher education, based on imbalances in terms of students' mobility.

Both the Swiss and the Nordic devices should deserve further examination and possibly be considered for application at the level of the EU or of the Bologna area.

\section{A.2 The Norwegian combination of loans and grants for student's life}

Norway - see Levy (2004) and Lanekassen (2008) - has a long tradition of designing financing systems for his higher education which goes back to the early post-World War II period.

Higher education in Norway is mostly public and free. Therefore there is actually no need for financial help for tuition fees. However financial help might be provided for the other costs related to studies. Since 1947 a single public institution - the Norwegian State Educational Loan Fund or Lanekassen in Norwegian - is in charge of the various instruments of the Norwegian State regarding higher education.

The means of that fund are primarily directed to Norwegian citizens but they are also available to foreigners, under some conditions.

The system of financial help consists of grants, loans and loans conditionally convertible into grants. A particular aspect of the system is that it is student targeted, not family targeted. Students are considered as the beneficiaries of the various helps. For Norwegian students staying home, a help of up to 10,000 EUR per academic year can be granted, initially as a loan; this loan, however, can be partially or completely converted into a grant. In order to receive the maximum grant, the Norwegian student has to live on his or her own, to pass all the examinations, to earn less than 14,000 EUR and to have assets not exceeding 28,000 EUR. Additional loans can be provided given the family situation, e.g. the fact that the student has dependent, like children.

For Norwegian students going abroad, the support is fully portable. Three main conditions must be checked therefore: the equivalent quality of the foreign host institution, the corresponding level of studies and the actual attendance to the lectures. There are five main types of available financial supports: a basic support, a support for travel expenses, a language grants, a tuition support and a supplementary tuition grant. Basic support is the same as for students staying in Norway and it is intended to cover all living and study costs, except tuition fees. The support given for travel expenses depends on the place of study. If a new language must be learned the student may receive a grant for this purpose. Since, unlike most other countries in the world, higher education is almost free in Norway, a support is given for tuition fees in the host country. Finally, for some highly prestigious institutions in some countries, like the US and UK, an additional support is provided in order to compensate especially high tuition fees. 
An original feature of the Norwegian system is that it provides the same support to foreigners as to nationals, under very generous conditions. As soon as he or she has been admitted in a Norwegian higher education institution and has obtained a residence permit, a foreign student may apply for a support from Norway. The foreign student is then treated as a Norwegian citizen. Foreign students eligible for support are those coming from the Nordic countries, from the member states of the European Economic Area, as well as those from Central and Eastern Europe, Central Asia and developing countries. Also eligible are political refugees, asylum seekers and immigrants, under some conditions. More generally, the Fund defines the countries whose citizens may benefit from its support.

Another important point is that Norway uses that financing scheme for pursuing numerous policy goals, even if success is variable. The design of the loan-grant mix, the relative weight given to each component and the conditions for converting a loan into a grant reflect the aims that Norway pursues.

The main objectives are supporting students during the time spent in a higher education institution, and enhancing equity through a larger access to higher education, especially for poor students. These aims however are standard. Some other goals are more original. First is the philosophy of welfare state common to Nordic countries. Let us mention two implications: the importance of caring for individual needs, hence the adaptation of help to the family situation; and the one of distributing general income among citizens in order to create social cohesion.

Concerning mobility, Norway aims to give an international character to its higher education by promoting both studies abroad of its residents, and stays in Norway of foreign students. Its very generous system makes it very easy for Norwegian students to support the costs of studying abroad. Similarly Norway tries to help developing countries by providing access to its system to foreign students coming from those countries: for those latter students, loans are completely converted into grants if they decide to return home and to work in their own country.

Another specific feature is the willingness of Norway to ensure a harmonious economic development of its different regions, even the most remote places. As an example, a Norwegian student who decides to work in some remote area of the country can have his loan completely converted into a grant.

To sum up, the Norwegian system has many interesting features and the design of the financial support to student is shaped in line with its higher education policy.

\section{A.3 The Australian system of contingent loans}

Australia has created a system of contingent loans to finance higher education and mobility of students - see Australian Government, Department of Education, Employment and Workplace Relations (2008). Higher education is financed by both the government and the students, through the so called Commonwealth contribution and student contribution. 
As a general rule, all students who attend Australian higher education are charged tuition fees. However several measures reduce the high of that contribution: most students are Commonwealth supported. This means that they are only required to pay a fraction of the tuition fees, called the student contribution, while the commonwealth pays the rest. Students can then defer the payment of their contribution through a HELP loan, called FEE-HELP. The Higher Education Loan Program, or HELP, offers free interest loans from the government to Australian citizens and to some permanent residents under some conditions. Other students are not Commonwealth supported; they must pay the full fee and they receive no direct government contribution to the cost of their education. HELP is jointly administered by the Department of Education, Science and Training, DEST, and the Australian Tax Office, ATO. In addition to these loans, some students are entitled to the Youth Allowance, to assist them financially during their studies. This help is means and assets tested.

FEE-HELP loans are interest free and must be repaid after graduation only if the beneficiary earns revenues above a given threshold; they thus are contingent loans. Another system is also available for mobile students, called OS-HELP. This is an additional loan aiming at covering the costs related to higher education abroad. It is refundable according to the same rules as FEE-HELP. However Australian citizens must be registered in an Australian institution and must not spend all their studies abroad. Each OS-HELP loan covers costs for six months and each beneficiary can only apply for two such loans over his or her lifetime. 


\section{CESifo Working Paper Series}

for full list see www.cesifo-group.org/wp

(address: Poschingerstr. 5, 81679 Munich, Germany, office@cesifo.de)

2329 Paolo M. Panteghini, Corporate Debt, Hybrid Securities and the Effective Tax Rate, June 2008

2330 Guglielmo Maria Caporale, Juncal Cuñado and Luis A. Gil-Alana, Modelling Long-Run Trends and Cycles in Financial Time Series Data, June 2008

2331 Avi Ben-Bassat and Momi Dahan, Social Identity and Voter Turnout, June 2008

2332 Martin R. West and Ludger Wößmann, "Every Catholic Child in a Catholic School”: Historical Resistance to State Schooling, Contemporary Private Competition, and Student Achievement across Countries, June 2008

2333 Erkki Koskela and Panu Poutvaara, Outsourcing and Labor Taxation in Dual Labor Markets, June 2008

2334 Philippe Choné and Laurent Linnemer, Optimal Litigation Strategies with Signaling and Screening, June 2008

2335 Albert Solé-Ollé and Pilar Sorribas-Navarro, Does Partisan Alignment Affect the Electoral Reward of Intergovernmental Transfers?, June 2008

2336 Antonio Cabrales and Piero Gottardi, Markets for Information: Of Inefficient Firewalls and Efficient Monopolies, June 2008

2337 Sumon Majumdar and Sharun W. Mukand, The Leader as Catalyst - on Leadership and the Mechanics of Institutional Change, June 2008

2338 Ulrich Hange, Tax Competition, Elastic Labor Supply, and Growth, June 2008

2339 Guy Laroque and Bernard Salanié, Does Fertility Respond to Financial Incentives?, June 2008

2340 Adriano Paggiaro, Enrico Rettore and Ugo Trivellato, The Effect of Extending the Duration of Eligibility in an Italian Labour Market Programme for Dismissed Workers, June 2008

2341 Helmut Seitz, Minimum Standards, Fixed Costs and Taxing Autonomy of Subnational Governments, June 2008

2342 Robert S. Chirinko, Leo de Haan and Elmer Sterken, Asset Price Shocks, Real Expenditures, and Financial Structure: A Multi-Country Analysis, July 2008

2343 Wolfgang Leininger, Evolutionarily Stable Preferences in Contests, July 2008

2344 Hartmut Egger and Udo Kreickemeier, Fairness, Trade, and Inequality, July 2008 
2345 Ngo Van Long and Bodhisattva Sengupta, Yardstick Competition, Corruption, and Electoral Incentives, July 2008

2346 Florian Baumann, Employment Protection: The Case of Limited Enforceability, July 2008

2347 Alessandro Balestrino, Cinzia Ciardi and Claudio Mammini, On the Causes and Consequences of Divorce, July 2008

2348 Dirk Schindler and Benjamin Weigert, Insuring Educational Risk: Opportunities versus Income, July 2008

2349 Lammertjan Dam and Ben J. Heijdra, The Environmental and Macroeconomic Effects of Socially Responsible Investment, July 2008

2350 Avner Greif, Contract Enforcement and Institutions among the Maghribi Traders: Refuting Edwards and Ogilvie, July 2008

2351 Helmuth Cremer, Philippe De Donder, Dario Maldonado and Pierre Pestieau, Habit Formation and Labor Supply, July 2008

2352 Francesco Menoncin and Paolo M. Panteghini, The Johansson-Samuelson Theorem in General Equilibrium: A Rebuttal, July 2008

2353 Michael Kaganovich and Itzhak Zilcha, Alternative Social Security Systems and Growth, July 2008

2354 Keith Blackburn, Kyriakos C. Neanidis and M. Emranul Haque, Corruption, Seigniorage and Growth: Theory and Evidence, July 2008

2355 Edward Castronova, A Test of the Law of Demand in a Virtual World: Exploring the Petri Dish Approach to Social Science, July 2008

2356 Harald Badinger and Peter Egger, GM Estimation of Higher-Order Spatial Autoregressive Processes in Cross-Section Models with Heteroskedastic Disturbances, July 2008

2357 Wolfgang Buchholz and Jan Schumacher, Discounting the Long-Distant Future: A Simple Explanation for the Weitzman-Gollier-Puzzle, July 2008

2358 Luca Anderlini, Leonardo Felli and Alessandro Riboni, Statute Law or Case Law?, July 2008

2359 Guglielmo Maria Caporale, Davide Ciferri and Alessandro Girardi, Are the Baltic Countries Ready to Adopt the Euro? A Generalised Purchasing Power Parity Approach, July 2008

2360 Erkki Koskela and Ronnie Schöb, Outsourcing of Unionized Firms and the Impacts of Labour Market Policy Reforms, July 2008 
2361 Francisco Alvarez-Cuadrado and Ngo Van Long, A Permanent Income Version of the Relative Income Hypothesis, July 2008

2362 Gabrielle Demange, Robert Fenge and Silke Uebelmesser, Financing Higher Education and Labor Mobility, July 2008

2363 Alessandra Casarico and Alessandro Sommacal, Labor Income Taxation, Human Capital and Growth: The Role of Child Care, August 2008

2364 Antonis Adam, Manthos D. Delis and Pantelis Kammas, Fiscal Decentralization and Public Sector Efficiency: Evidence from OECD Countries, August 2008

2365 Stefan Voigt, The (Economic) Effects of Lay Participation in Courts - A Cross-Country Analysis, August 2008

2366 Tobias König and Andreas Wagener, (Post-)Materialist Attitudes and the Mix of Capital and Labour Taxation, August 2008

2367 Ximing Wu, Andreas Savvides and Thanasis Stengos, The Global Joint Distribution of Income and Health, August 2008

2368 Alejandro Donado and Klaus Wälde, Trade Unions Go Global!, August 2008

2369 Hans Gersbach and Hans Haller, Exit and Power in General Equilibrium, August 2008

2370 Jan P.A.M. Jacobs and Jan-Egbert Sturm, The Information Content of KOF Indicators on Swiss Current Account Data Revisions, August 2008

2371 Oliver Hülsewig, Johannes Mayr and Timo Wollmershäuser, Forecasting Euro Area Real GDP: Optimal Pooling of Information, August 2008

2372 Tigran Poghosyan and Jakob de Haan, Determinants of Cross-Border Bank Acquisitions in Transition Economies: A Latent Class Analysis, August 2008

2373 David Anthoff and Richard S.J. Tol, On International Equity Weights and National Decision Making on Climate Change, August 2008

2374 Florian Englmaier and Arno Schmöller, Reserve Price Formation in Online Auctions, August 2008

2375 Karl Farmer, Birgit Friedl and Andreas Rainer, Effects of Unilateral Climate Policy on Terms of Trade, Capital Accumulation, and Welfare in a World Economy, August 2008

2376 Monika Bütler, Stefan Staubli and Maria Grazia Zito, The Role of the Annuity’s Value on the Decision (Not) to Annuitize: Evidence from a Large Policy Change, August 2008

2377 Inmaculada Martínez-Zarzoso, The Impact of Urbanization on $\mathrm{CO}_{2}$ Emissions: Evidence from Developing Countries, August 2008 
2378 Brian Roberson and Dmitriy Kvasov, The Non-Constant-Sum Colonel Blotto Game, August 2008

2379 Ian Dew-Becker, How Much Sunlight Does it Take to Disinfect a Boardroom? A Short History of Executive Compensation Regulation, August 2008

2380 Cécile Aubert, Oliver Falck and Stephan Heblich, Subsidizing National Champions: An Evolutionary Perspective, August 2008

2381 Sebastian Buhai, Miguel Portela, Coen Teulings and Aico van Vuuren, Returns to Tenure or Seniority?, August 2008

2382 Erkki Koskela and Jan König, Flexible Outsourcing, Profit Sharing and Equilibrium Unemployment, August 2008

2383 Torberg Falch and Justina AV Fischer, Does a Generous Welfare State Crowd out Student Achievement? Panel Data Evidence from International Student Tests, September 2008

2384 Pedro Gomes and François Pouget, Corporate Tax Competition and the Decline of Public Investment, September 2008

2385 Marko Koethenbuerger, How Do Local Governments Decide on Public Policy in Fiscal Federalism? Tax vs. Expenditure Optimization, September 2008

2386 Ronald McKinnon and Gunther Schnabl, China’s Exchange Rate Impasse and the Weak U.S. Dollar, September 2008

2387 Yan-Leung Cheung, Yin-Wong Cheung and Alan T.K. Wan, A High-Low Model of Daily Stock Price Ranges, September 2008

2388 Louis Eeckhoudt and Harris Schlesinger, Changes in Risk and the Demand for Saving, September 2008

2389 Carsten Hefeker and Blandine Zimmer, Uncertainty and Fiscal Policy in an Asymmetric Monetary Union, September 2008

2390 Jay Pil Choi and Byung-Cheol Kim, Net Neutrality and Investment Incentives, September 2008

2391 Marcel Gérard, Financing Bologna, the Internationally Mobile Students in European Higher Education, September 2008 